\title{
The Implementation of Class Action Research (CAR) by Japanese Language Teachers in Indonesia
}

\author{
Nuria Haristiani, Diana Rizki Oktarina \\ Program Studi Pendidikan Bahasa Jepang, Sekolah Pascasarjana \\ Universitas Pendidikan Indonesia, Bandung, Indonesia \\ nuriaharist@upi.edu
}

\begin{abstract}
A B S T R A C T
This study aims to determine the implementation of Classroom Action Research (CAR) conducted by Japanese language teachers in Indonesia at this time. A qualitative descriptive research method was used in this study to describe the questionnaire result from 193 participants in the first session of webinar, and 203 participants in the second session. Based on the results of the questionnaire, it was found that most of the participants had never done CAR at all or had never done CAR in a structured manner. Participants who have done CAR mostly use it for promotion and only a small number use it for teaching development. This research cannot represent the overall field conditions but is expected to provide an overview of the current CAR implementation by Japanese language teachers in Indonesia, and the development of teaching materials that can be developed through routine CAR.
\end{abstract}

K E Y W O R D S

Classroom Action Research; Community Service; Japanese Teachers

$\begin{array}{cc}\text { A R T I C L E } & \text { I N F O } \\ \text { First received: } 05 \text { October } 2021 & \text { Final proof accepted: } 04 \text { December } 2021\end{array}$

Available online: 19 December 2021

\section{PENDAHULUAN}

Pembelajaran di sekolah dapat berkembang tidak hanya dikarenakan oleh satu faktor saja. Hal ini sesuai dengan penjelasan Kunlasomboon, Wongwanich, dan Suwanmonkha (2015), yaitu bahwa konsep pembelajaran organisasi seperti proses individu berbagi pengetahuan dan perilaku untuk melakukan hal-hal baru, dilibatkan dalam pembelajaran sekolah, dan proses inilah yang akan mendorong interaksi antar anggota (siswa dan guru), adanya pengetahuan yang dibagikan, adanya pembelajaran yang masuk ke dalam sistem organisasi (sekolah), juga perkembangan yang berkelanjutan. Jadi dapat diketahui bahwa banyak faktor yang dapat membantu mengembangkan suatu pembelajaran menjadi lebih baik, dari segi sistem, pengajar, maupun siswa.

Untuk meningkatkan kualitas dan mengembangkan proses belajar dan pembelajaran tentu tidaklah mudah. Berbagai tantangan dari berbagai aspek dan faktor mungkin dihadapi. Seperti penggunaan metode pengajaran yang tidak tepat, kurangnya waktu pengajaran, siswa yang tidak dapat memahami apa yang guru sampaikan, dan masalah lainnya yang dapat 
menghambat proses tersebut. Dalam suatu pengajaran, tidak menutup kemungkinan bahwa adanya kekurangan seperti yang telah disebutkan dan hal tersebut dapat diatasi dengan dilakukannya Penelitian Tindakan Kelas (PTK). Hal tersebut sesuai dengan pendapat Latif, Sari, dan Riyadi (2017), yaitu kekurangan dalam pengajaran dapat diatasi salah satunya dengan PTK.

PTK adalah salah satu metode untuk mencari suatu hal yang efektif atau berhasil untuk dapat meningkatkan pembelajaran siswa (Mettetal, 2002b). Mettetal (2002a) menambahkan bahwa PTK membantu pengajar mendapatkan keputusan yang tepat dalam praktik mengajarnya berdasarkan suatu penyelidikan secara sistematis terhadap apa yang terjadi pada situasi tertentu di kelasnya. Sejalan dengan hal tersebut, Idris, Eskender, Yosief, Demoz, dan Andemicael (2020) menjelaskan bahwa meningkatkan suatu pengajaran memang merupakan sebuah tantangan bagi seorang guru, namun kualitas pengajaran dapat ditingkatkan jika eksplorasi yang mendalam mengenai PTK dilakukan. Jadi, PTK dapat membantu seorang pengajar mendapatkan jalan keluar untuk membantu memecahkan masalah yang terjadi di kelasnya, termasuk dalam bidang pengajaran bahasa Jepang. Walaupun, dalam pelaksanannya dapat muncul kesulitan seperti kurangnya pengetahuan guru tentang pembuatan proposal PTK yang menjadi salah satu kesulitan utama. Latif, Sari, dan Riyadi (2017) juga menambahkan bahwa kompetensi guru dalam melakukan PTK menjadi salah satu komponen penting dalam pelaksanaan PTK.

Dalam pengajaran bahasa Jepang, kesulitan yang muncul cukup beragam, yang dapat disebabkan oleh perbedaan huruf, tata bahasa, pelafalan, dan lainnya. Tidak hanya dari kesulitan siswa mempelajari hal tersebut, metode penyampaian materi yang tidak tepat, pelafalan pengajar yang kurang tepat, atau sistem pengajaran yang tidak sesuai dapat menyebabkan masalah dalam pembelajaran bahasa Jepang. Maka dari itu, sebagai pengajar perlu untuk selalu berusaha membuat pengajarannya menjadi lebih baik lagi, sesuai dengan penjelasan Kunlasomboon, Wongwanich, dan Suwanmonkha (2015) mengenai pengembangan pengajaran. Hal ini diperkuat oleh pendapat Karlina, Djuanda, Kurnia, Sunarya, dan Sunaengsih (2020) yang menjelaskan bahwa seorang guru harus melaksanakan penelitian untuk mendukung pelaksanaan pembelajaran agar proses belajar mengajar dalam berjalan dengan baik. Jadi, dapat disimpulkan bahwa PTK, khususnya dalam pengajaran bahasa Jepang, perlu untuk dilakukan. Selain itu, kualitas seorang guru harus ditingkatkan lagi menjadi standar yang lebih tinggi, karena hal ini berpengaruh pada pengembangan pendidikan yang berkelanjutan yang bisa dilakukan secara teoritis maupun dengan melaksanakan penelitian tindakan kelas (Meesuk, Sramoon, \& Wongrugsa, 2020).

Sebelumnya, penelitian mengenai PkM sudah banyak dilakukan. Beberapa di antaranya adalah penelitian Karlina, Djuanda, Kurnia, Sunarya, dan Sunaengsih (2020) untuk meningkatkan kompetensi guru dengan karya tulis ilmiah untuk menghadapi revolusi industri 4.0, dilihat dari penulisan dan pelaksanaan PTK. Dari penelitian tersebut didapatkan hasil berupa adanya penyamaan persepsi dalam menulis PTK, yang selanjutnya agar dapat digunakan untuk kenaikan jabatan fungsional dan dapat sering dilakukan untuk peningkatan pengajaran. Sastromiharjo, Mulyati, dan Idris (2021) juga meneliti tentang bahan ajar daring, dengan diadakannya pelatihan untuk meningkatkan kemampuan profesional untuk guru bahasa Indonesia tingkat SMP. Pelatihan ini mendapatkan respon positif dan dirasa bermanfaat untuk meningkatkan kemampuan para guru. Pelatihan seperti ini diharapkan dapat diupayakan untuk terus dilanjutkan secara berkesinambungan. Selanjutnya, Ruhaliah, Sudaryat, Isnendes, dan Hendrayana (2020) juga melakukan penelitian tentang pelatihan penyususan perangkat pembelajaran khususnya menggunakan micro learning. Dalam pengajaran bahasa Sunda, micro learning seperti Google Form, Podcast, dan sebagainya, dapat menjadi alternatif media yang membuat pengajaran jadi lebih menarik. Hal tersebut didukung oleh Mardani dan Padmadewi (2020) yang menjelaskan bahwa keterampilan mengajar guru juga dapat ditingkatkan salah satunya dengan micro teaching yang oleh para siswa dianggap sangat bermanfaat.

Penelitian mengenai PTK dalam bahasa Jepang juga sudah dilkakukan, beberapa di antaranya adalah PTK terkait meningkatkan kemampuan membaca bahasa Jepang oleh Oesman dan Wardhana (2013). Penelitian tersebut fokus pada peningkatan kemampuan pengajar dan proses belajar khususnya dalam basic reading di salah satu jurusan bahasa Jepang di 
Semarang. Berdasarkan hasil penelitian tersebut diketahui bahwa adanya perkembangan peran guru sehingga hasil belajar siswa dapat meningkat dengan cooperative learning dan siswa menjadi lebih aktif. Penelitian lainnya terkait komunikasi dan bahasa Jepang dilakukan oleh Hamidah dan Hoftman (2020). Penelitian tersebut bertujuan untuk memahami kompetensi berbicara yang dimiliki siswa, bagaimana meningkatkan kompetensi tersebut, dan metode yang tepat untuk meningkatkan kompetensi tersebut. Didapatkan hasil bahwa kemampuan dari $68 \%$ siswa masih kurang dari $70 \%$. Oleh karena itu, harus dilakukan penyusunan bahan ajar yang tepat dan dirancang secara khusus untuk meningkatkan kemampuan berbicara siswa. Penelitian lainnya mengenai kompetensi guru bahasa Jepang dalam ruang lingkup kota juga pernah dilakukan oleh Prasetiani (2014) di kota Semarang. Penelitian ini mengidentifikasi hasil pelatihan dari workshop untuk peningkatkan kompetensi guru bahasa Jepang se-kota Semarang. Dari hasil penelitian, diperoleh informasi bahwa para peserta merasa antusias, terlihat dari banyaknya pertanyaan yang diajukan dan diskusi dalam kelompoknya. Para pengajar juga memiliki keinginan untuk melakukan PTK, namun masih kurang dalam hal motivasi. Dari workshop ini didapatkan hasil juga bahwa pemahaman para pengajar mengenai PTK dan proposalnya jadi lebih meningkat. Walaupun, dalam penelitian ini ada pembahasan yang kurang tepat pada bagian kesimpulan yang membicarakan tentang pengajaran akuntasi yang tidak sesuai dengan pengajaran bahasa Jepang yang sedang dibahas.

Berbeda dari penelitian-penelitian tersebut, penelitian ini memiliki ruang lingkup pengajar yang lebih luas, yaitu pengajar bahasa Jepang di seluruh Indonesia. Penelitian ini juga mencoba untuk memahami bagaimana kondisi sebenarnya yang dirasakan oleh para pengajar Bahasa Jepang se-Indonesia secara garis besar. Terutama terkait dengan bagaimana manfaat PTK, kendala dalam membuat proposal dan melakukan PTK, serta urgensi diadakannya workshop mengenai PTK khususnya dalam bidang pengajaran bahasa Jepang. Diharapkan dengan didapatkannya hasil dari jawaban - jawaban tersebut dapat menjadi masukan untuk diadakannya pelatihan mengenai PTK, khususnya bahasa Jepang, dari awal pembuatan proposal, hingga selesainya pelaksanaan PTK yang kemudian dapat digunakan untuk mengembangkan pengajaran bahasa Jepang, mulai dari masing-masing instansi para pengajar.

\section{METODE}

\section{Instrumen Penelitian dan Sumber Data}

Kegiatan workshop ini menjadi salah satu wadah pendidikan masyarakat yang bertujuan untuk meningkatkan pemahaman serta kesadaran pengajar bahasa Jepang mengenai PTK. Kegiatan ini diikuti oleh 202 peserta dengan 193 orang pengajar bahasa Jepang tingkat SMA atau universitas di Indonesia yang berpartisipasi dalam kegiatan workshop PTK sesi 1, dan 209 peserta dengan 203 orang pengajar bahasa Jepang pada kegiatan sesi 2 .

Tabel 1: Pertanyaan angket sesi 1 dan sesi 2.

\begin{tabular}{|c|c|}
\hline \multicolumn{2}{|r|}{ Pertanyaan Pendaftaran Sesi 1 dan 2} \\
\hline 1 & Apakah Bapak/Ibu pernah membuat PTK? \\
\hline 2 & Jika YA, digunakan untuk kepentingan apa? \\
\hline \multicolumn{2}{|r|}{ Penilaian Workshop Sesi 1 dan 2} \\
\hline 1 & $\begin{array}{l}\text { Bagaimana tingkat kepuasan Anda terhadap } \\
\text { workshop PTK ini? }\end{array}$ \\
\hline 2 & $\begin{array}{l}\text { Apakah Workshop PTK ini bermanfaat untuk } \\
\text { Anda? }\end{array}$ \\
\hline 3 & Apa tujuan Anda mengikuti workshop PTK ini? \\
\hline 4 & $\begin{array}{l}\text { Tema apa yang Anda inginkan untuk workshop } \\
\text { atau kegiatan serupa selanjutnya? }\end{array}$ \\
\hline 5 & Komentar dan Saran \\
\hline \multicolumn{2}{|r|}{ Angket Sesi 1} \\
\hline 1 & Apakah menurut Anda PTK perlu dilakukan? \\
\hline 2 & $\begin{array}{l}\text { Menurut Anda, apa yang dapat menjadi kendala } \\
\text { saat Anda ingin melakukan PTK? }\end{array}$ \\
\hline 3 & $\begin{array}{l}\text { Menurut Anda PTK bermanfaat untuk (pilih } \\
\text { yang sesuai, dapat memilih jawaban lebih dari } \\
\text { satu): } \\
\text { [Meningkatkan kualitas PBM] } \\
\text { [Meningkatkan kemampuan belajar siswa] } \\
\text { [Memperbaiki perilaku siswa] } \\
\text { [Meningkatkan kualitas kinerja guru] } \\
\text { [Meningkatkan kapasitas guru (jabatan, pangkat, } \\
\text { dsb)] } \\
\text { [Melatih kemampuan problem solving guru] }\end{array}$ \\
\hline \multicolumn{2}{|r|}{ Angket Sesi 2} \\
\hline 1 & Apakah menurut Anda PTK perlu dilakukan? \\
\hline 2 & $\begin{array}{l}\text { Permasalahan apa yang Anda hadapi dalam } \\
\text { menulis proposal PTK? }\end{array}$ \\
\hline
\end{tabular}


Data angket dikumpulkan menggunakan Google Form, yang dibagikan setelah kegiatan workshop selesai. Data diambil dari angket kegiatan workshop penelitian Tindakan kelas pada tanggal 28 Agustus 2021 untuk sesi 1, dengan tema Teori dan Praktek Penelitian Tindakan Kelas (PTK) Pendidikan Bahasa Jepang. Sedangkan, sesi 2 diadakan pada tanggal 4 September 2021 dengan tema Penulisan Proposal Praktek Penelitian Tindakan Kelas (PTK) dan Best Practice. Pengisian angket dilakukan mulai tanggal 28 Agustus hingga 16 September 2021 untuk kedua sesi tersebut. Angket sesi 1 dan sesi 2 , terdiri dari angket pendaftaran (2 pertanyaan), penilaian terhadap kegiatan workshop (8 pertanyaan), dan pemahaman mengenai PTK (11 pertanyaan pada sesi 1,10 pertanyaan pada sesi 2). Tabel 1 menunjukkan pertanyaan-pertanyaan yang ada pada angket Google Form untuk sesi 1 dan 2.

Penelitian ini hanya akan membahas beberapa pertanyaan yang memiliki pengaruh terhadap kemampuan dan pemahaman para pengajar bahasa Jepang terhadap PTK yang bisa dilihat pada Tabel 1.

\section{Metode Penelitian dan Analisis Data}

Penelitian ini menggunakan metode deskriptif kualitatif untuk menjabarkan hasil angket mengenai PTK Setelah kegiatan workshop dilakukan, angket dibagikan pada akhir acara dan peserta diharuskan mengisi angket secara keseluruhan. Setelah data angket terkumpul, dipilih data yang sesuai dengan rumusan masalah penelitian ini. Selanjutnya, data dikategorikan menjadi kelompok yang sesuai, seperti pengalaman, tujuan, kendala dan manfaat melakukan PTK, serta penilaian, komentar dan saran terhadap kegiatan workshop PTK yang dilakukan.

\section{HASIL DAN PEMBAHASAN}

\section{Pengalaman dan Tujuan Guru Melakukan PTK}

Data yang diperoleh dari angket yang dibagikan setelah workshop PTK ini selesai, kemudian dikategorikan menjadi beberapa kelompok seperti yang akan dijelaskan pada bab berikut. Pembahasan yang dilakukan langsung dilakukan setelah dijelaskan mengenai hasil yang didapatkan berdasarkan angket. Selanjutnya, hasil angket yang merupakan kondisi nyata atau gambaran pemahaman PTK pengajar bahasa Jepang di Indonesia, dapat dijadikan masukan untuk kegiatan yang akan dilakukan di kemudian hari. Berdasarkan jawaban angket dari kegiatan workshop PTK ini, sesuai yang dapat dilihat pada Grafik 1 dan 2.

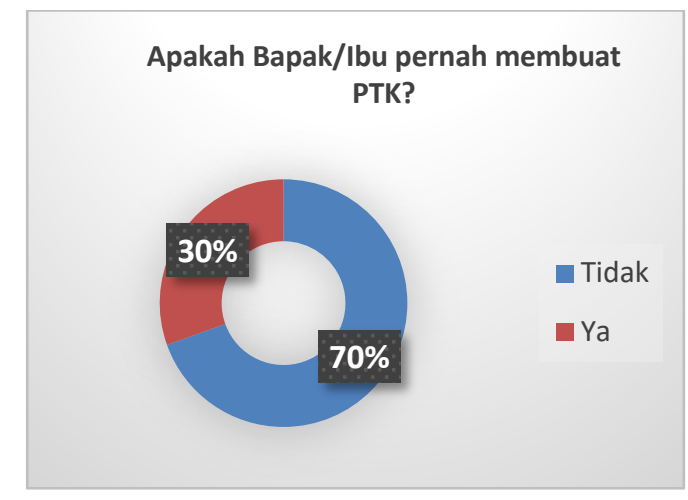

Grafik 1: Pengalaman responden dalam melakukan PTK (sesi 1).

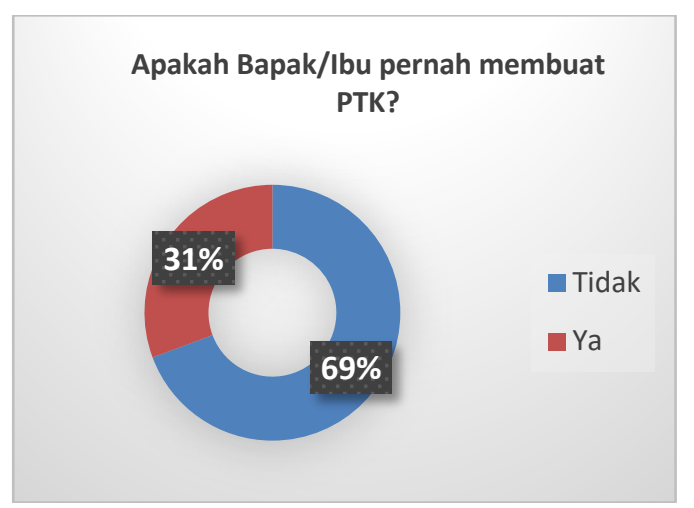

Grafik 2: Pengalaman responden dalam melakukan PTK (sesi 2).

Grafik 1 dan 2 menunjukkan bahwa sekitar $70 \%$ pengajar bahasa Jepang saat ini belum pernah melakukan PTK. Hal ini dapat berarti bahwa para pengajar tersebut, belum pernah melakukan PTK sama sekali, atau belum pernah melakukan penelitian terkait PTK berdasarkan tahapan PTK yang seharusnya, dengan kata lain tanpa adanya perancangan proposal dan penulisan laporan secara khusus. Di sisi lain, PTK yang dilakukan secara mendalam lebih baik dilakukan sebagai salah satu proses pengembangan pengajaran sesuai dengan pendapat Latif, Sari, dan Riyadi (2017) dan Idris, 
Eskender, Yosief, Demoz, dan Andemicael (2020). Sedangkan, sekitar $30 \%$ pengajar yang mengikuti kegiatan workshop ini pernah melakukan PTK dengan tujuan yang beragam seperti pada Grafik 3 dan 4.

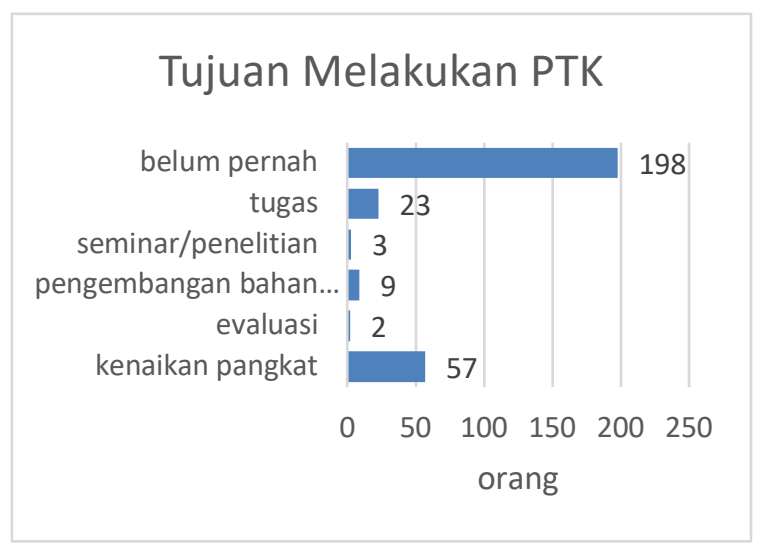

Grafik 3: Tujuan responden melakukan PTK (sesi 1).

\section{Tujuan Melakukan PTK}

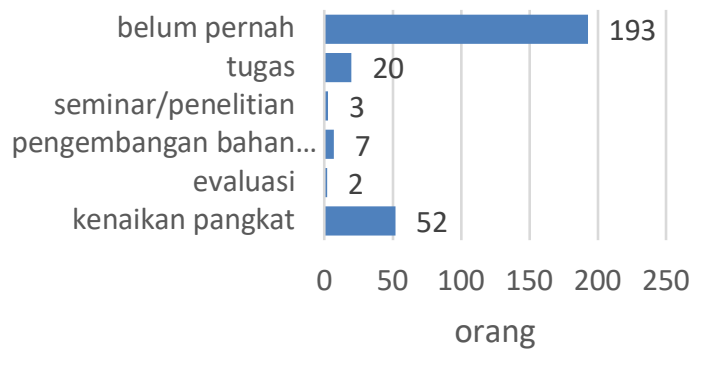

Grafik 4: Tujuan responden melakukan PTK (sesi 2).

Dari hal ini dapat diketahui bahwa pelaksanaan PTK dalam pengajaran bahasa Jepang di Indonesia, yang sebagian besar adalah pengajaran di tingkat SMA masih minim. Dalam kenyataannya, kemungkinan para pengajar tersebut pernah melakukan PTK secara tidak sadar, contohnya ketika membuat bahan ajar, mengevaluasi, dan kemudian menggunakan kembali bahan ajar yang sudah dikembangkan, yang merupakan salah satu contoh dari pelaksanaan PTK. Hanya saja, jika tidak berdasarkan prosedur, atau tanpa mengikuti aturan PTK yang sebenarnya, hal tersebut bisa menjadi salah satu bentuk ketidaksempurnaan dalam proses pengembangan pengajaran. Dengan dilakukannya PTK yang terstruktur, baik laporan secara tertulis, poin-poin yang harus dikembangkan pun akan semakin jelas, sehingga dapat mengatasi masalah yang terdapat dalam kelas pengajar tersebut dan menjadikan pengembangan pengajarannya dapat berhasil. Hal ini sesuai dengan apa yang dijelaskan oleh Kunlasomboon, Wongwanich, dan Suwanmonkha (2015) mengenai pengembangan pengajaran.

Hal ini sesuai dengan jawaban para pengajar dari pertanyaan tujuan melakukan PTK. Grafik 3 adalah tujuan melakukan PTK yang diberikan oleh pengajar bahasa Jepang yang berpartisipasi pada sesi 1, sedangkan Grafik 4 adalah tujuan yang diberikan oleh partisipan pada sesi 2. Lebih dari 190 orang pendaftar dalam workshop ini belum pernah melakukan PTK, yang dimaksud belum pernah di sini mungkin secara terstruktur. Sedangkan, alasan terbanyak kedua adalah PTK digunakan untuk menjadi salah satu syarat kenaikan pangkat. Di sisi lain, tujuan utama PTK sebagai pengembangan bahan ajar berada pada posisi rendah dengan rata-rata delapan orang yang melakukannya.

Dalam hal ini, dapat disimpulkan bahwa tujuan utama PTK yang dipahami oleh para pengajar bahasa Jepang saat ini adalah sebagai salah satu syarat kenaikan pangkat. Pemahaman bahwa PTK itu penting atau seharusnya dijadikan alasan utama untuk pengembangan bahan ajar, yang merupakan salah satu kewajiban seorang pengajar, menjadi terlupakan. Dengan hasil jawaban ini perlu diperhatikan lagi agar pelaksanaan PTK menjadi suatu kebiasaan baik yang dapat dilakukan oleh para pengajar, sebagai salah satu bentuk kontribusinya untuk mengembangkan bahan ajar yang juga dilakukan untuk meningkatkan kualitas seorang guru sesuai dengan pendapat Meesuk, Sramoon, dan Wongrugsa (2020). Maka dari itu, sebelum dilakukan PTK, pemahaman mengenai pelaksanaan PTK nya itu sendiri harus dimiliki oleh para pengajar. Dari hal tersebut, penjelasan Latif, Sari, dan Riyadi (2017) mengenai kompetensi PTK guru adalah komponen yang penting dapat dipahami.

Dengan diadakannya workshop ini diharapkan setidaknya para pengajar dapat mendapatkan manfaat mengenai ilmu PTK yang harus lebih dipertimbangkan sebagai salah satu bentuk pengembangan pengajaran. Rata-rata dari dua sesi workshop yang diadakan, $67,5 \%$ peserta memberikan nilai kepuasan terhadap workshop dengan poin penuh (5 poin) yaitu kategori "sangat puas", $29,5 \%$ memberikan nilai 4 poin yaitu 
kategori "puas", dan sisanya memilih poin 1-3. Lalu, rata-rata dari kedua sesi, dengan persentase $99,5 \%$ dari total jumlah peserta, menyatakan bahwa PTK itu bermanfaat. Tabel 2 menunjukkan nilai kepuasan untuk kegiatan workshop dan kebermanfaatan PTK bagi masingmasing pengajar pada setiap sesi dan rata-ratanya. Selain itu, rata-rata $99,9 \%$ peserta dari kedua sesi menyatakan bahwa PTK perlu dilakukan. Hal ini sejalan dengan pendapat Sastromiharjo, Mulyati, dan Idris (2021), bahwa pelatihan itu sangat bermanfaat dan diupayakan untuk terus berlanjut.

Tabel 2: Penilaian terhadap workshop dan PTK.

\begin{tabular}{|c|c|c|c|c|c|}
\hline \multirow{2}{*}{ No } & Angket & & $\begin{array}{c}\text { Sesi } \\
\mathbf{1} \\
\mathbf{( \% )}\end{array}$ & $\begin{array}{c}\text { Sesi } \\
\mathbf{2} \\
\mathbf{( \% )}\end{array}$ & $\begin{array}{c}\text { Rata- } \\
\text { rata } \\
\mathbf{( \% )}\end{array}$ \\
\hline \multirow{2}{*}{$\begin{array}{c}\text { Penilaian } \\
\text { Workshop }\end{array}$} & $\begin{array}{c}\text { Sangat } \\
\text { Puas }\end{array}$ & 67 & 68 & $\mathbf{6 7 , 5}$ \\
\cline { 3 - 6 } & Puas & 31 & 28 & $\mathbf{2 9 , 5}$ \\
\cline { 3 - 6 } & $\begin{array}{c}\text { Cukup } \\
\text { Puas }\end{array}$ & 1 & 3 & 2 \\
\cline { 3 - 6 } & $\begin{array}{c}\text { Tidak } \\
\text { Puas }\end{array}$ & 0 & 0,5 & 0,25 \\
\cline { 3 - 6 } & $\begin{array}{c}\text { Sangat } \\
\text { Tidak } \\
\text { Puas }\end{array}$ & 1 & 0,5 & 0,75 \\
\hline \multirow{2}{*}{$\begin{array}{c}\text { PTK itu } \\
\text { bermanfaat }\end{array}$} & $\begin{array}{c}\text { Sangat } \\
\text { Setuju }\end{array}$ & 77 & 72 & $\mathbf{7 4 , 5}$ \\
\cline { 3 - 6 } & Setuju & 20 & 25,5 & $\mathbf{2 2 , 7 5}$ \\
\cline { 3 - 6 } & $\begin{array}{c}\text { Cukup } \\
\text { Setuju }\end{array}$ & 0 & 1,5 & 0,75 \\
\cline { 3 - 6 } & $\begin{array}{c}\text { Tidak } \\
\text { Setuju }\end{array}$ & 2 & 0,5 & 1,25 \\
\cline { 3 - 6 } & $\begin{array}{c}\text { Sangat } \\
\text { Tidak } \\
\text { Setuju }\end{array}$ & 1 & 0,5 & 0,75 \\
\hline
\end{tabular}

\section{Manfaat dan Kendala Guru dalam Melakukan PTK}

Partisipan juga diberikan pertanyaan mengenai manfaat dari PTK, sesuai dengan Grafik 5, dan memilih manfaat berdasarkan jawaban yang tersedia, atau mengisikan sendiri jawabannya pada bagian "lainnya". Empat alasan paling banyak untuk manfaat PTK adalah meningkatkan kualitas PBM (93\%), Meningkatkan kemampuan belajar siswa (91\%), meningkatkan kualitas kinerja guru (85\%), dan meningkatkan kemampuan problem solving guru (85\%). PTK dianggap cukup untuk meningkatkan kapasitas guru terkait jabatan, pangkat, dan lainnya (60\%), juga untuk memperbaiki perilaku siswa. Tapi,
PTK dianggap tidak terlalu berpengaruh untuk memperbaiki kualitas instansi (43\%).

Manfaat PTK (\%)

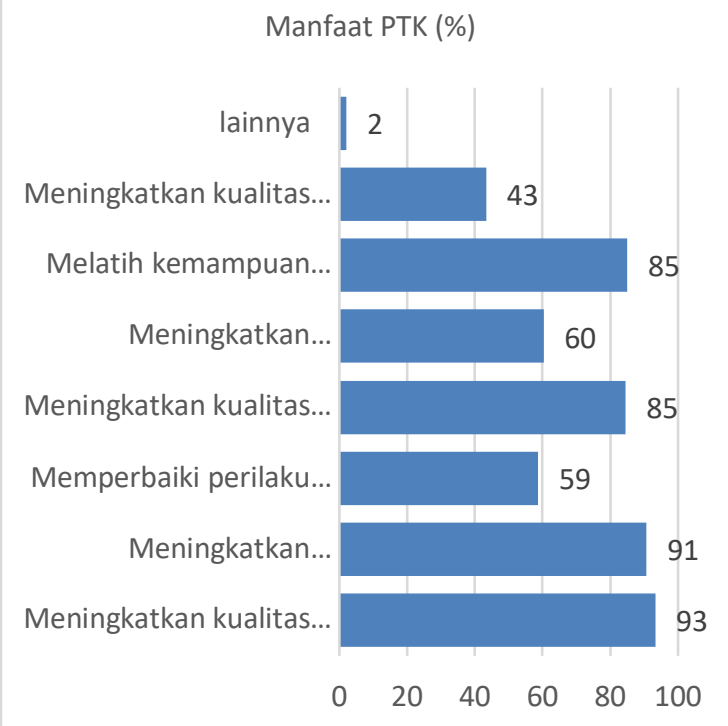

Grafik 5: Manfaat PTK menurut responden.

Selain alasan-alasan yang dipilih oleh partisipan, pendapat lainnya mengenai manfaat PTK yang berasal dari empat partisipan juga disampaikan, yaitu untuk menemukan gaya belajar yang cocok untuk pembelajar bahasa Jepang di Indonesia, meningkatkan hasil belajarnya melalui tindakan guru yang inovatif dan kreatif, meningkatkan kemampuan guru dalam melakukan penelitian, dan menjadi kesempatan bagi guru untuk mengembangkan pengetahuan dan keterampilannya sendiri dan meningkatkan kualitas pendidikan karena selalu ada pembaharuan atau perbaikan PBM. Dari hasil inilah terlihat bahwa workshop ini memberikan gambaran bahwa PTK dapat bermanfaat bagi pengembangan pengajaran dari berbagai aspek yang telah disebutkan pada Grafik 5, sesuai dengan Mettetal (2002a), bahwa PTK dapat membantu pengajar. Di sisi lain, responden juga mengalami kendala dalam melakukan PTK. Dalam angket juga diajukan pertanyaan mengenai kendala dan masalah yang dihadapi ketika melakukan PTK, termasuk membuat proposal dan best practice yang disimpulkan sesuai dengan Tabel 3. 
Tabel 3: Kendala dalam melaksanakan PTK.

\begin{tabular}{|l|c|c|c|}
\hline $\begin{array}{l}\text { PTK, Proposal, Best } \\
\text { Practice Dan } \\
\text { Permasalahannya }\end{array}$ & $\begin{array}{c}\text { Sesi 1 } \\
\text { (\%) }\end{array}$ & $\begin{array}{c}\text { Sesi } \\
\mathbf{2} \text { (\%) }\end{array}$ & $\begin{array}{c}\text { Rata- } \\
\text { Rata } \\
\text { (\%) }\end{array}$ \\
\hline Banyak & 0.5 & 0.5 & 0.5 \\
\hline Belum Pernah & 3.0 & 2.6 & 2.8 \\
\hline $\begin{array}{l}\text { Dasar Pemikiran / } \\
\text { Teori }\end{array}$ & 19.7 & 11.9 & $\mathbf{1 5 . 8}$ \\
\hline $\begin{array}{l}\text { Dukungan Atasan / } \\
\text { Dana / Administrasi / } \\
\text { Institusi / Observer }\end{array}$ & 4.4 & 5.2 & 4.8 \\
\hline Kondisi Daring & 1.0 & 18.7 & 9.8 \\
\hline Merumuskan Masalah & 9.9 & 3.1 & 6.5 \\
\hline $\begin{array}{l}\text { Metode / Terbatasnya } \\
\text { Media Pembelajaran }\end{array}$ & 10.3 & 5.2 & 7.8 \\
\hline Niat / Motivasi / Ide & 24.6 & 9.3 & $\mathbf{1 7 . 0}$ \\
\hline $\begin{array}{l}\text { Partisipasi / Minat / } \\
\text { Kemampuan Siswa }\end{array}$ & 5.9 & 10.9 & 8.4 \\
\hline $\begin{array}{l}\text { Penyusunan / } \\
\text { Pelaksanaan / } \\
\text { Penulisan / } \\
\text { Pengmpulan Data }\end{array}$ & 17.7 & 14.0 & $\mathbf{1 5 . 9}$ \\
\hline $\begin{array}{l}\text { Tidak Ada Pembimbing } \\
\text { / Rekan Diskusi }\end{array}$ & 3.0 & 6.7 & 4.8 \\
\hline $\begin{array}{l}\text { Tidak Ada Solusi } \\
\text { Penyelesaian Masalah }\end{array}$ & 0.0 & 1.0 & 0.5 \\
\hline Waktu & $\mathbf{1 2 . 3}$ & $\mathbf{2 1 . 8}$ & $\mathbf{1 7 . 0}$ \\
\hline
\end{tabular}

Jika dilihat dari rata-rata kendala atau masalah yang dihadapi, para pengajar merasa kesulitan untuk mengatur waktu dan mendapatkan motivasi untuk melakukan PTK. Hal ini sesuai dengan pendapat Prasetiani (2014) bahwa motivasi dari para guru juga sangat berpengaruh pada pelaksanaan PTK. Tidak hanya kondisi tersebut, masalah pemahaman mengenai teori dan bagaimana menyusun PTK menjadi kendala terbanyak kedua dari kendala lainnya. Walaupun cukup banyak kendala yang terjadi, peengajar harus berusaha untuk melakukan pengembangan bahan ajar dimulai dari langkah kecil yang waktunya bisa disesuaikan. Sesuai dengan Karlina, Djuanda, Kurnia, Sunarya, dan Sunaengsih (2020) yang menjelaskan bahwa seorang pengajar harus melakukan penelitian untuk membantu pengajarannya.

\section{Tujuan Guru Mengikuti Workshop PTK}

Jika dilihat berdasarkan tujuannya, tujuan para pengajar dalam mengikuti workshop ini cukup beragam, dan dapat disimpulkan seperti pada Tabel 4. Dengan mengikuti kegiatan workshop ini, sebagian besar dari partisipan ingin mendapatkan ilmu mengenai PTK. Hal tersebut bisa dilihat dari 124 dari 193 peserta (pada sesi 1), dan 153 dari 203 peserta (pada sesi 2) bertujuan untuk memperoleh ilmu mengenai PTK. Hal ini berkaitan dengan belum pernahnya kebanyakan dari pengajar yang mengikuti workshop ini melakukan PTK yang telah disebutkan di awal pembahasan. Dengan inilah diharapkan kompetensi pengajar mengenai PTK dapat meningkat.

Tabel 4: Tujuan mengikuti workshop PTK.

\begin{tabular}{|c|c|c|}
\hline Tujuan & $\begin{array}{c}\text { Sesi } 1 \\
\text { (peserta) }\end{array}$ & $\begin{array}{c}\text { Sesi } 2 \\
\text { (peser } \\
\text { ta) }\end{array}$ \\
\hline Ilmu PTK & 124 & 153 \\
\hline Membuat PTK & 41 & 20 \\
\hline 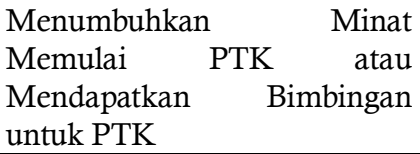 & 13 & 6 \\
\hline Kenaikan Pangkat & 5 & 13 \\
\hline $\begin{array}{lr}\text { Meningkatkan } & \text { Kualitas atau } \\
\text { Mengatasi } & \text { Masalah } \\
\text { Pembelajaran } & \\
\end{array}$ & 3 & 5 \\
\hline $\begin{array}{l}\text { Menjalin Kejasama Antar } \\
\text { Sesama Pengajar }\end{array}$ & 1 & 0 \\
\hline 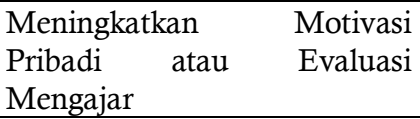 & 1 & 6 \\
\hline $\begin{array}{ll}\text { Mengetahui } & \text { Perkembangan } \\
\text { PTK di SMA } & \\
\end{array}$ & 1 & 0 \\
\hline Meningkatkan Motivasi Siswa & 1 & 0 \\
\hline Memahami Siswa & 1 & 0 \\
\hline- & 2 & 0 \\
\hline Jumlah & 193 & 203 \\
\hline
\end{tabular}

\section{Masukan Guru untuk Pelaksanaan Workshop PTK}

Partisipan juga memberikan komentar dan saran terkait workshop ini yang juga dapat dikaitkan dengan tercapai atau tidak tujuan masing-masing pengajar dengan diadakannya workshop ini. Tidak semua partisipan memberikan komentar dan/atau sarannya, tapi seperti yang bisa dilihat pada Tabel 5 , total 135 orang dari total peserta sesi 1 dan 2 , menyatakan bahwa workshop ini sudah baik / bermanfaat. 
Tabel 5: Komentar dan saran untuk workshop PTK.

\begin{tabular}{|c|c|}
\hline Komentar Dan Saran & $\begin{array}{l}\text { Jumlah } \\
\text { (Orang) }\end{array}$ \\
\hline $\begin{array}{lll}\text { Baik / Bermanfaat (Ilmu Dan } \\
\text { Wawasan) }\end{array}$ & 135 \\
\hline Lebih Sering Lagi Diadakan & 89 \\
\hline Waktu Kurang & 51 \\
\hline Coaching / Praktek / Sharing PTK & 28 \\
\hline Tema Lain / ke-Jepang-an & 13 \\
\hline
\end{tabular}

Dengan kata lain, dapat memberikan ilmu dan wawasan kepada para pesertanya. PTK ini dapat dikatakan berhasil untuk setidaknya menyampaikan bahwa PTK merupakan salah satu kegiatan yang perlu dilakukan dan memiliki manfaat untuk pengembangan pengajaran khususnya bahasa Jepang, yang pasti bergerak dinamis seiring berjalannya waktu. Sesuai dengan Kunlasomboon, Wongwanich, dan Suwanmonkha (2015), bahwa pengajaran bergerak berdasarkan sistem. Jika ada satu hal yang berubah, sektor lainnya dapat berubah.

Tabel 6: Saran untuk tema pengabdian kepada masyarakat $(\mathrm{PkM})$.

\begin{tabular}{|l|c|c|c|}
\hline \multicolumn{1}{|c|}{ Tema Selanjutnya } & $\begin{array}{c}\text { Sesi } \\
\mathbf{1}(\mathbf{\%})\end{array}$ & $\begin{array}{c}\text { Sesi 2 } \\
\mathbf{( \% )}\end{array}$ & $\begin{array}{c}\text { Rata- } \\
\text { Rata } \\
\mathbf{( \% )}\end{array}$ \\
\hline $\begin{array}{l}\text { Metode Pengajaran / } \\
\text { Model Pembelajaran / } \\
\text { Penilaian }\end{array}$ & 24.4 & 25.6 & 25.0 \\
\hline $\begin{array}{l}\text { Media Interaktif / } \\
\text { Aplikasi }\end{array}$ & 15.0 & 22.2 & 18.6 \\
\hline $\begin{array}{l}\text { PTK / Best Practice / } \\
\text { Praktek PTK / Lanjutan }\end{array}$ & 14.5 & 14.8 & 14.6 \\
\hline $\begin{array}{l}\text { Pembelajaran Daring / } \\
\text { Blended Learning }\end{array}$ & 14.0 & 14.8 & 14.4 \\
\hline $\begin{array}{l}\text { Pengajaran Matkul } \\
\text { Khusus Bahasa Jepang }\end{array}$ & 11.4 & 10.3 & 10.9 \\
\hline $\begin{array}{l}\text { Membuat Buku / Modul } \\
\text { / Soal / Bahan Ajar }\end{array}$ & 8.8 & 5.9 & 7.4 \\
\hline Penelitian Pembelajaran & 5.7 & 5.4 & 5.6 \\
\hline $\begin{array}{l}\text { Meningkatkan Minat / } \\
\text { Kemampuan Pembelajar }\end{array}$ & 5.2 & 4.4 & 4.8 \\
\hline Apa Saja & 4.1 & 3.4 & 3.8 \\
\hline $\begin{array}{l}\text { Pengembangan Profesi / } \\
\text { Klinik Simlitabmas/Sinta }\end{array}$ & 3.6 & 2.5 & 3.0 \\
\hline $\begin{array}{l}\text { Karya Inovatif Guru / } \\
\text { Sharing Dari Guru }\end{array}$ & 3.1 & 2.5 & 2.8 \\
\hline Kurikulum & 2.6 & 1.5 & 2.0 \\
\hline Bahasa Jepang SMK & 1.0 & 1.0 & 1.0 \\
\hline PkM & 0.5 & 0.5 & 0.5 \\
\hline Pembelajaran Aktif & 0 & 0.3 \\
\hline
\end{tabular}

Sebagai masukan untuk workshop selanjutnya, diajukan juga pertanyaan mengenai tema untuk PkM selanjutnya, baik dalam bentuk workshop atau seminar. Dengan pertanyaan ini juga, diharapkan dapat memberikan gambaran kondisi nyata permasalahan selain PTK yang dihadapi oleh para pengajar bahasa Jepang di Indonesia saat ini. Hal ini dapat dilihat pada Tabel 6. Selain kendala, permasalahan, dan tema yang telah diberikan oleh para peserta, pengembangan kegiatan PkM workshop PTK ini menjadi sebuah pelatihan atau coaching PTK pada tiap daerahnya juga diharapkan oleh peserta.

\section{KESIMPULAN}

PTK merupakan salah satu cara untuk melakukan pengemabgan pengajaran yang perlu dilakukan oleh para pengajar, khususnya dalam pengajaran bahasa Jepang. Namun, kondisi nyatanya masih banyak pengajar bahasa Jepang yang belum pernah melakukan PTK secara terstruktur, dan belum memahami manfaat dari PTK. Dari angket, dapat diketahui bahwa sebagian besar pengajar belum pernah melakukan PTK, dan yang sudah melakukan PTK, digunakan untuk kenaikan pangkat. Tujuan utama PTK sebagai bentuk pengembangan pengajaran cukup terlupakan. Dengan diadakannya workshop ini, para pengajar mulai memahami bahwa PTK dilakukan untuk pengembangan pengajaran yang perlu dilakukan secara rutin, yang merupakan salah satu peran pengajar untuk berkontribusi terhadap pendidikan. Cukup banyak kendala seperti motivasi, waktu, pemahaman teori, dan tata cara penulisan yang dapat menjadi penghambat dilakukannya PTK untuk pengajar bahasa Jepang saat ini. Namun, sebagai solusi dari hal tersebut dapat dilakukan pelatihan PTK secara mendalam, yang dapat dilakukan secara khusus tiap daerah, dan dapat menjadi masukan untuk kegiatan PkM dan penelitian selanjutnya.

\section{UCAPAN TERIMA KASIH}

Tim peneliti/penulis mengucapkan terimakasih kepada Sekolah Pascasarjana UPI yang telah mendanai kegiatan Pengabdian kepada Masyarakat ini dengan no. kontrak penelitian/PkM: 0836/UN40.LP/PT.01.03/2021. 


\section{REFERENSI}

Hamidah, A., \& Hoftman, R. O. (2020). Tingkat Kompetensi Komunikasi Bahasa Jepang (Penelitian Tindakan Kelas Mahasiswa Semester Vii Bahasa Jepang STBA JIA Bekasi 2019/2020). Ennichi, 1(2).

Idris, K. M., Eskender, S., Yosief, A., Demoz, B., \& Andemicael, K. (2020). Exploring Headway Pedagogies in Initial Teacher Education Through Collaborative Action Research into Processes of Learning: Experiences from Eritrea. Nordic Journal of Comparative and International Education (NJCIE), 4(3-4), 139-156.

Karlina, D. A, Djuanda, D., Kurnia, D., Sunarya, D. T., \& Sunaengsih, C. (2020). Meningkatkan Kompetensi Guru melalui Karya Tulis Ilmiah untuk Menyongsong Era Revolusi Industri 4.0. Jurnal Pasca Dharma Pengabdian Masyarakat, 1(1), 6-9.

Kunlasomboon, N., Wongwanich, S., \& Suwanmonkha, S. (2015). Research and development of classroom action research process to enhance school learning. Procedia-Social and Behavioral Sciences, 171, 1315-1324.

Latif, I., Sari, D., \& Riyadi, M. (2017). Teachers' Competence in Creating Classroom Action Research (CAR) Proposal. Advances in Social Science, Education and Humanities Research (ASSEHR), 158, 372-380. In International Conference on Teacher Training and Education 2017 (ICTTE 2017).

Mardani, D. M. S., \& Padmadewi, N. N. The perception of Japanese language education students about microteaching. JAPANEDU: Jurnal Pendidikan dan Pengajaran Bahasa Jepang, 5(2), 69-81.
Meesuk, P., Sramoon, B., \& Wongrugsa, A. (2020). Classroom action research-based instruction: The sustainable teacher professional development strategy. Journal of Teacher Education for Sustainability, 22(1), 98-110.

Mettetal, G. (2002a). Improving teaching through classroom action research. Essays on teaching excellence: Toward the best in the Academy, 14(7).

Mettetal, G. (2002b). The what, why and how of classroom action research. Journal of the Scholarship of Teaching and Learning, 2(1), 6.

Oesman, A. M., \& Wardhana, C. K. (2013). Upaya Meningkatkan Kemampuan Memahami Bacaan Bahasa Jepang Tingkat Dasar Melalui Model Pembelajaran Cooperative Learning Teknik Script (Penelitian Tindakan Kelas Pada Mahasiswa Semester II Prodi Pendidikan Bahasa Jepang Unnes). Izumi, 2(2).

Prasetiani, D. (2014). Peningkatan Kompetensi Penelitian Tindakan Kelas Bagi Guru Bahasa Jepang SMA/SMK Se-kota Semarang. Jurnal Abdimas, 18(1).

Ruhaliah, R., Sudaryat, Y., Isnendes, R., \& Hendrayana, D. (2020). Pelatihan Penyusunan Perangkat Pembelajaran "Merdeka Belajar" Bagi Guru Bahasa Sunda Di Kota Sukabumi. Dimasatra, 1(1).

Sastromiharjo, A., Mulyati, Y., \& Idris, N. S. (2021). Sosialisasi Bahan Ajar Daring bagi Guru-guru Bahasa Indonesia SMP Se-Kabupaten Sukabumi. Jurnal Pasca Dharma Pengabdian Masyarakat, 2(1), 3945. 